\title{
THE HISTOLOGY OF LUNG CANCER
}

\author{
BY \\ J. B. WALTER AND D. M. PRYCE \\ From the Bland Sutton Institute of Patho'ogy and Institute for Clinical Research, Middlesex Hospital, the \\ Department of Morbid Anatomy, St. Mary's Hospital, London, and Harefield Hospital
}

(RECEIVED FOR PUBLICATION MARCH 23, 1955)

With the great advances in thoracic surgery, radical excision for pulmonary carcinoma has become a relatively safe and frequent operation, offering to the patient new hope of cure. However, if the results of operative treatment are to be accurately assessed, the ordinary gross pathology must be carefully and fully recorded, for it is of little use comparing survival rates unless attention is paid not only to the different histological types of growth, but also to anatomical factors such as location, size, and site of origin, which can seriously affect the outcome.

At present there is no uniformity in histological nomenclature and the site of origin is a matter of dispute. This paper gives our views on histology after a recent study of 207 surgical specimens and 159 necropsies.

\section{Material AND Methods}

The material was derived from the lung resections for bronchial carcinoma at Harefield Hospital (161 cases), the Middlesex Hospital (35 cases), and the London Chest Hospital (11 cases), during the period 1950 to 1953 . The specimens were unselected and consecutive, with the exception of some which had been destroyed and three from patients who had received pre-operative radiotherapy, and the operations were performed by many surgeons.

The specimens were inflated with formol saline and after fixation sectioned by thin slices in the parasagittal plane. Each tumour was examined with special reference to its size, anatomical location, and site of origin. The number of blocks taken for microscopy depended upon the size of the tumour; from some small growths only one block was taken, but from large tumours as many as 12 pieces of tissue were sectioned. A necropsy series of pulmonary carcinoma was also examined histologically. This consisted of all the necropsies on lung cancer during the period 1948 to 1953 at the Middlesex Hospital (102 cases) and those for 1952 at St. Mary's Hospital (57 cases).

\section{Histological Classification}

The histological classification of malignant epithelial tumours of the lung presents many difficulties and numerous classifications have been put forward in the past. It is generally recognized that the vast majority of tumours arise in the epithelium lining the bronchi and bronchioles. It appears that they arise in the basal layer, and, as in many nonmalignant conditions these cells are capable of differentiation into cells of different function and structure, it is not surprising that this adaptability is mirrored in tumour formation.

The simpler classifications recognize two groups. Ormerod (1937) divided his cases into squamous and non-squamous carcinomata, while Rienhoff (1947), regarding the small-cell and cylindrical-cell tumour as forms of adenocarcinomata, divided his cases into squamous and adenocarcinomata. Other authors (O'Keefe, 1948; Björk, 1947; Graham, 1941) have also found difficulty in separating smallcell carcinomata from adenocarcinomata.

In most classifications the squamous-cell tumour is described as an entity and it is the non-squamous types which have caused the most difficulty. Koletsky (1938) divided the non-squamous tumours into small-cell and adenocarcinoma, and Gebauer (1941) added another group, carcinoma simplex, which formed five of his 158 proved cases. The terms anaplastic, undifferentiated, large-cell, smallcell, oat-cell, and carcinoma simplex have all been used to describe growths which were not obviously either squamous or adenocarcinomatous, and it is evident that there is no agreed classification. Even those authors who use similar terms give such divergent percentages of the various types that comparison is difficult and in some cases impossible.

Bryson and Spencer (1951) recognized five groups in their 866 necropsy cases (Table I), while Buchberg, Lubliner, and Rubin (1951) classified their series of 320 cases into three groups. Both used the term adenocarcinoma, but whereas this growth was the most common in Buchberg's series, constituting 
TABLE I

PUBLISHED CLASSIFICATIONS OF NECROPSY MATERIAL*

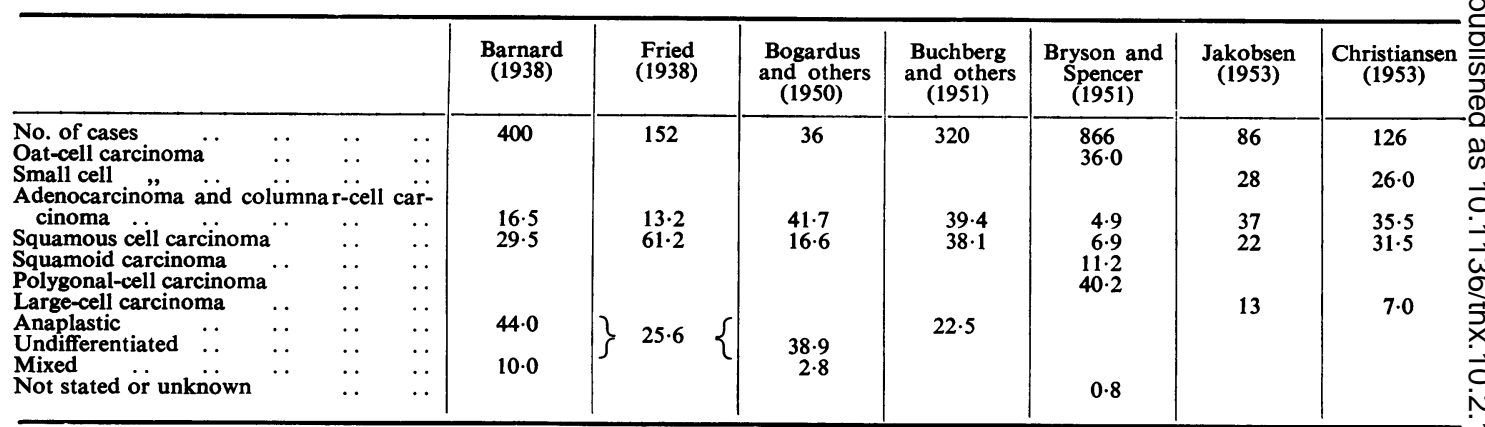

* Figures are expressed as a percentage, and adenomata are excluded wherever possible.

TABLE II

PUBLISHED CLASSIFICATIONS OF CLINICAL OR SURGICAL MATERIAL*

\begin{tabular}{|c|c|c|c|c|c|c|c|c|c|c|c|}
\hline & $\begin{array}{c}\text { Ormerod } \\
\text { (1937) }\end{array}$ & $\begin{array}{c}\text { Gebauer } \\
(1941)\end{array}$ & $\begin{array}{c}\text { Ochsner } \\
\text { and others } \\
(1948) \dagger\end{array}$ & $\begin{array}{c}\text { Shorvon } \\
\text { (1947) }\end{array}$ & $\begin{array}{c}\text { Bogardus } \\
\text { and others } \\
(1950)\end{array}$ & $\begin{array}{l}\text { Phillips } \\
\text { and others } \\
(1950) \dagger\end{array}$ & $\begin{array}{c}\text { Brooks } \\
\text { and others } \\
(1951)\end{array}$ & $\begin{array}{c}\text { McDonald } \\
\text { and others } \\
(1951)\end{array}$ & $\begin{array}{l}\text { Brown } \\
\text { (1952) }\end{array}$ & $\begin{array}{c}\text { Kreyberg } \\
\text { (1952) }\end{array}$ & $\begin{array}{l}\text { Aufses } \\
\text { (1953) }\end{array}$ \\
\hline 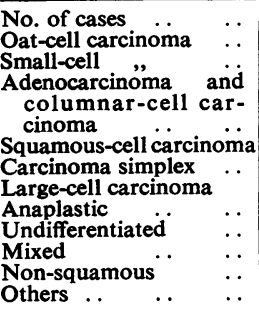 & 100 & $\begin{array}{r}158 \\
33 \cdot 5 \\
\\
20 \cdot 3 \\
38 \cdot 6 \\
3 \cdot 2 \\
\end{array}$ & $\begin{array}{l}22 \cdot 7 \\
39 \cdot 5 \\
37 \cdot 8 \ddagger\end{array}$ & $\begin{array}{r}3.8 \\
32.9 \\
41.8 \ddagger \\
21.5\end{array}$ & $\begin{array}{r}5.6 \\
44.4 \\
\\
38.9 \\
11 \cdot 1\end{array}$ & $\begin{array}{r}0 \\
75\end{array}$ & $\begin{array}{r}13.0 \\
48.7 \\
\\
2.9 \\
4.6 \\
0.7 \\
11.1\end{array}$ & $\begin{array}{r}849 \\
8.8 \\
\\
13 \cdot 2 \\
37.8 \\
40.2\end{array}$ & $\begin{array}{r}4 \cdot 4 \\
31 \cdot 3 \\
64 \cdot 3 \ddagger\end{array}$ & $\begin{array}{r}8.6 \\
55.6 \\
9.9 \\
4.9\end{array}$ & $\begin{array}{r}710 \\
11.0 \\
\\
19.9 \\
47.7 \\
0.8 \\
20.6\end{array}$ \\
\hline
\end{tabular}

* Figures expressed as a percentage, and adenomata are excluded wherever possible. † Series of resected specimens. $¥$ Stated to include oat-cell growths.

$39.4 \%$, Bryson and Spencer found it to be the least common $(4.9 \%)$. Similarly the incidence of squamous-cell carcinomata in necropsy material varies from $6.9 \%$ (Bryson and Spencer) to $61.2 \%$ (Fried, 1938).

Published classifications of surgical or clinical material show equally divergent results (Table II). McDonald, McBurney, Carlisle, and Patton (1951), McBurney, McDonald, and Clagett (1951), Carlisle, McDonald, and Harrington (1951), and Patton, McDonald, and Moersch (1951a and b) from the Mayo Clinic recognized four groups-small cell, large cell, squamous, and adenocarcinoma; Kreyberg (1952) adopted a similar terminology except that a fifth group of mixed adeno- and squamouscell carcinoma was added. However, the large-cell group constituted $40.2 \%$ in the Mayo Clinic figures, but only $9.9 \%$ in those of Kreyberg. Aufses (1953) did not use this term " large-cell carcinoma," but had an anaplastic group which formed $20.6 \%$ of his 710 cases. Small-cell tumours were grouped separately, and this is of interest in view of Barnard's inclusion of the oat-cell carcinoma amongst his $\stackrel{2}{x}$ anaplastic tumours (Barnard, 1938).

There are many possible explanations of these divergent figures; local factors influencing selection of cases, geographical, and racial variations may all play some part. Christiansen (1953) has 욱 produced evidence that of recent years there has $D$ been a change in the incidence of the various histological types of carcinoma. It is impossible $N$ to be certain about the relative importance of these various factors, but we consider that much of the $\tilde{D}$ variation is due to different interpretations by $\omega$ individual histologists. In a recent survey of lung cancer in eight London hospitals, Galluzzi and 0 Payne (personal communication, 1955) found that amongst the non-squamous tumours the incidence $?$ of adenocarcinoma varied from $6.0 \%$ at the Royal 0 Marsden Hospital to $31.0 \%$ at St. Mary Abbots

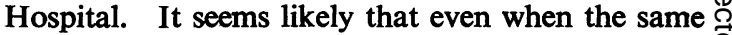
terms are used by different pathologists an identical $\stackrel{\unrhd}{\complement}$ tumour might be put into different categories. Thus an adenocarcinoma containing squamous elements 
might be included with the adenocarcinomata by one author, in a mixed group by another, and unless an adequate number of sections is examined, even with the squamous group. It is obviously important that not only should the morphological types be clearly described and defined, but that the manner in which the classification is worked must be clearly indicated.

In view of the confusing histological picture which lung cancer presents, some authors have attempted simplification in the terminology by adopting the view that there is only one entity, cancer of the lung, but that this may show considerable variation in structure. Barnard (1938), while dividing his 400 cases into squamous-cell carcinomata $(29.5 \%)$, columnar-celled $(16.5 \%)$, mixed $(10 \%)$, and anaplastic carcinomata $(44 \%)$, stated that, although the histological picture in any one case may be simple and consisting of only one type of growth, the more complex tumours consisting of two or more elements were more common. According to Willis (1948) individual tumours show various structural combinations, and great pleomorphism is possible in one tumour. His findings in 86 necropsy cases were:

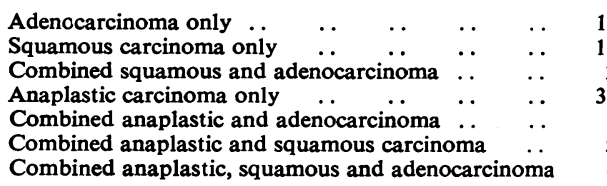

Such classification is legitimate, for the appearance of each tumour is described and the interpretation of these findings is left to the reader. Some tumours certainly present a complex histological picture, but by adopting certain criteria we found that all our cases could be classified into one of the following types: (1) Oat-cell carcinoma, (2) squamous-cell carcinoma, (3) adenocarcinoma, (4) polygonal-cell carcinoma, and (5) invasive and metastasizing " adenoma."

The terms used in this classification do not differ from those used by many previous authors, and it is only in the practical interpretation of histological findings that our classification can be at variance with that used by many histologists.

The difficulties encountered, however, are dependent not only upon the basic appearances of the growth but upon certain secondary, possibly degenerative, changes which may obscure the picture. These are squamous metaplasia, clear cell formation, and giant cell formation. Since these changes are not peculiar to any one type of growth, it is convenient to describe them later.
(1) OAt-Cell Carcinoma.-The epithelial origin of the " oat-cell tumour" was first propounded by Barnard in 1926, but since that time many authors have avoided the term (for example, Ewing, 1940). We think that the oat-cell carcinoma is an entity and that the term should be retained. The characteristic feature of these tumours is the relatively small cells with round, oval or oat-shaped hyperchromatic nuclei and scanty, ill-defined cytoplasm (Fig. 1). They undoubtedly arise from the bronchial or bronchiolar epithelium (Fig. 2).

Barnard (1926) noted the occasional occurrence of tubules in oat-cell carcinomata and regarded this as evidence of the epithelial nature of the growth. In a subsequent publication (Barnard, 1938) attempted tubule formation is again noted. On the other hand many histologists have been impressed by the uniformity of the oat-cell growths (Bryson and Spencer, 1951; Fried, 1938) and they appear to have placed in other groups those tumours showing tubular spaces. It is likely therefore that the oat-cell tumours have variously been classified as adenocarcinomata (Rienhoff, 1947), small-cell (Jakobsen, 1953), anaplastic (Barnard, 1938), undifferentiated (Bogardus, Adams, and Phillips, 1950 ) or even, where squamous metaplasia is present, as squamous, squamoid, or polygonal.

In $52 \%$ of the surgically removed oat-cell carcinomata in our series, the growth was uniform and conformed to the appearances generally regarded as typical of oat-cell tumours. In the remaining $48 \%$, however, the histological picture was not uniform and definite evidence of differentiation was present. This consisted of the formation of tubules and rosettes. In two tumours, one from each series, differentiation was so extraordinarily well marked in places that they would be classified by most observers as adenocarcinomata (Figs. 3 and 4). Nevertheless the cells in both differentiated and undifferentiated parts were hyperchromatic and typically oat type. In other cases, differentiation was not so marked; tubules were less well formed and appeared as rosettes (Fig. 5). In all these differentiated oat-cell tumours, staining for mucus was negative.

The appearance of these tumours is reminiscent of that seen in neuroblastoma or retinoblastoma, but since nearly half the oat-cell tumours in the surgical series showed rosettes or tubules, it is unreasonable to think that they could all be secondary to unidentified primary growths elsewhere in the body.

(2) Squamous-cell Carcinoma.-Tumours were included in this group only if two criteria were fulfilled: (i) The tumours showed keratinization or 


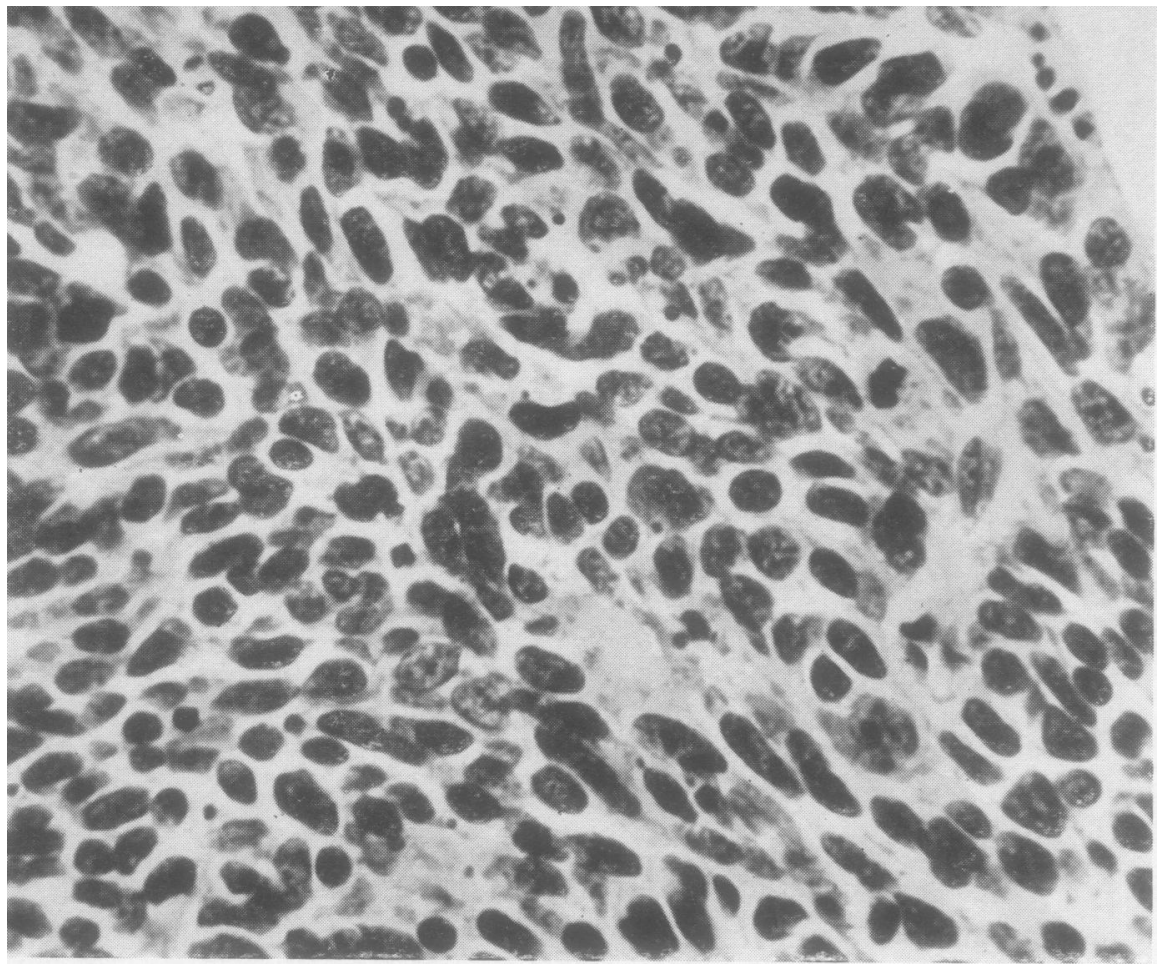

FIG. 1-Haematoxylin and eosin. Undifferentiated oat-cell carcinoma, o

590.

FIG. 2.-Haematoxylin and eosin. Oatcell carcinoma arising from bron- $\omega$ chial epithelium, $\times 320$.

FIG. 3.-Haematoxylin and eosin. Welldifferentiated oat-cell carcinoma showing tubule formation, $\times 190$. N

FIG. 1
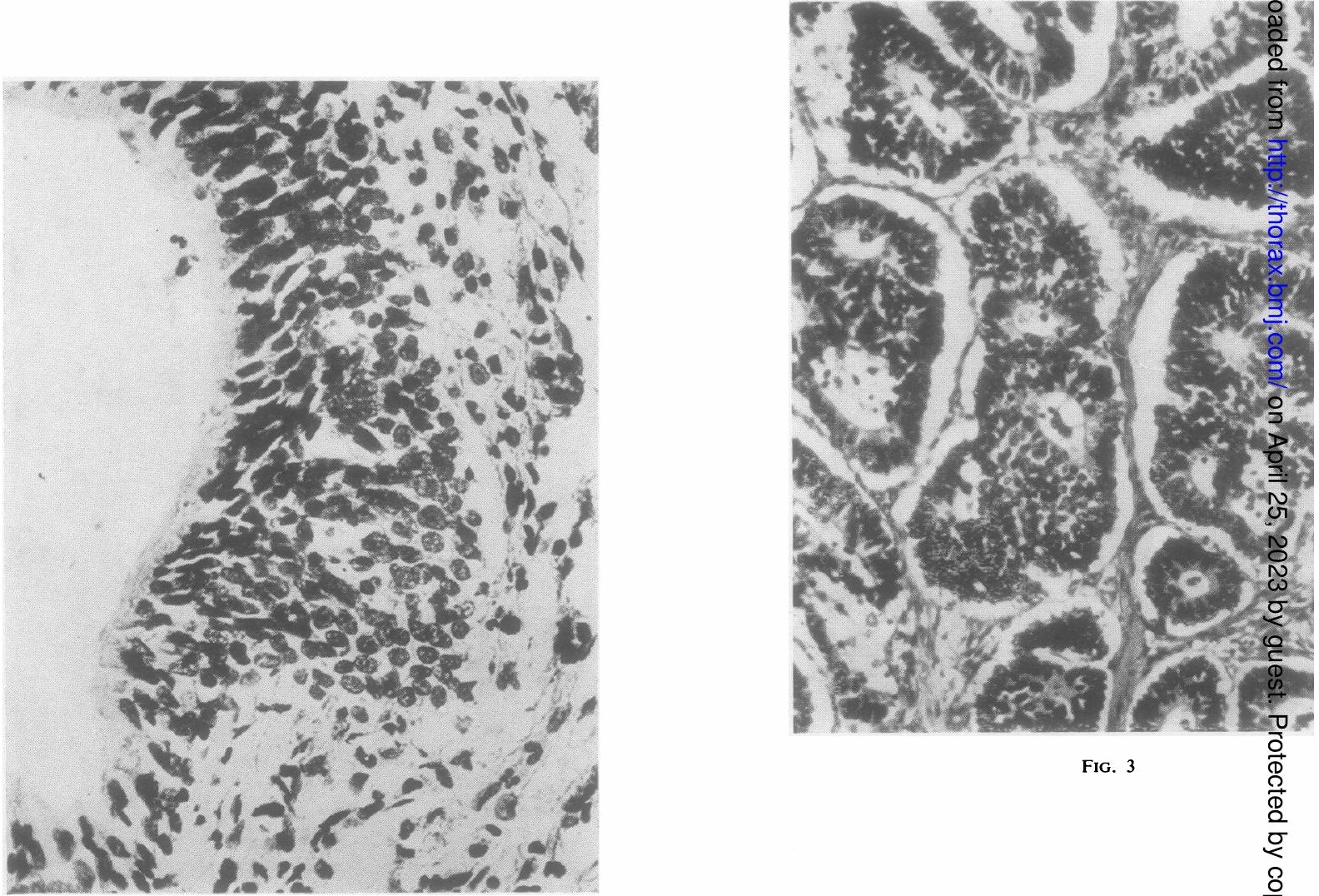

FIG. 3 


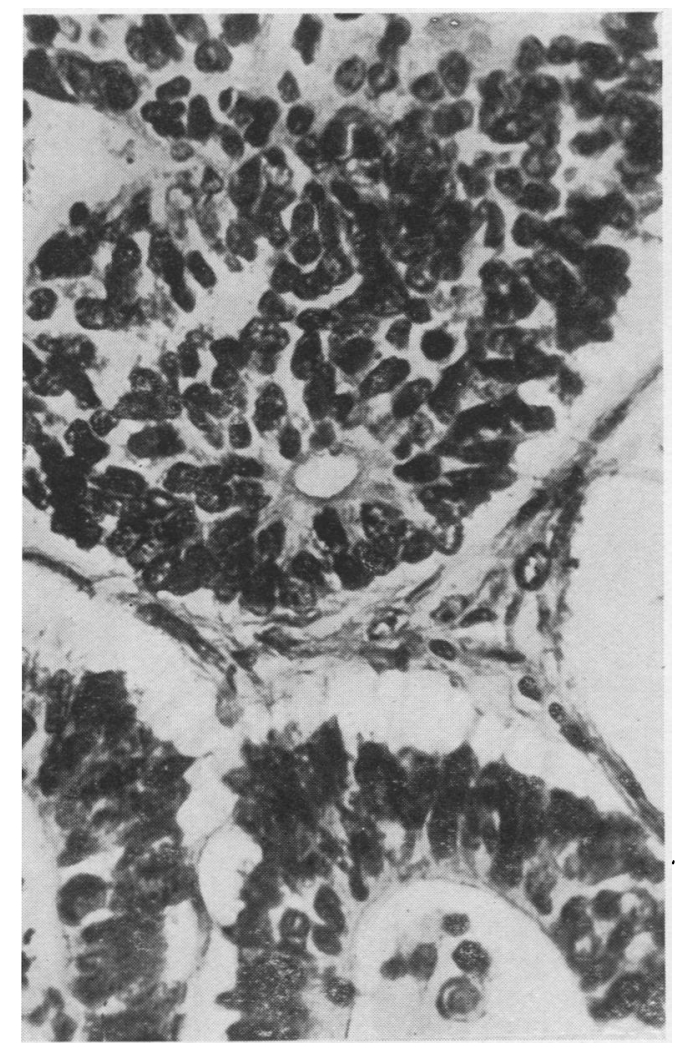

FIG. 4

Fig. 4.-Haematoxylin and eosin. Welldifferentiated oat-cell carcinoma (same case as Fig. 3) showing that the cells lining the tubules are of oat type, $\times 435$.

Fig. 5.-Haematoxylin and eosin. Oatcell carcinoma showing rosettes, $\times 520$.

FIG. 6.-Haematoxylin and eosin. Squamous-cell carcinoma, $\times 190$.

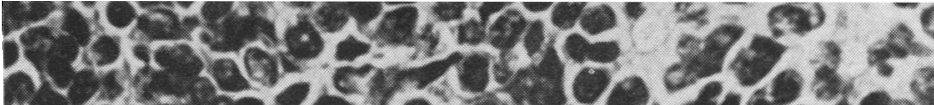

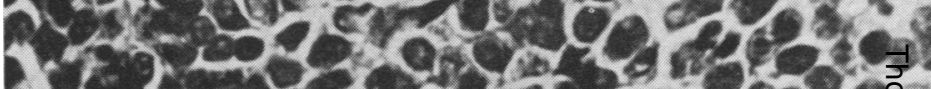

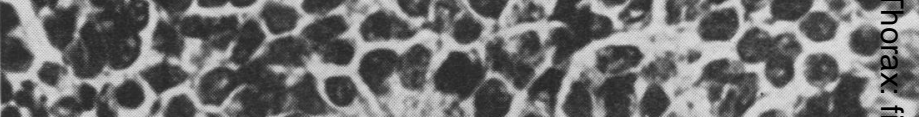

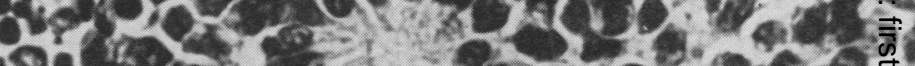

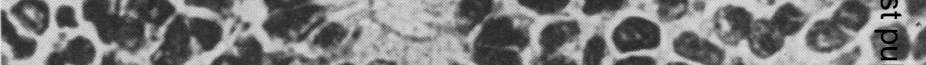

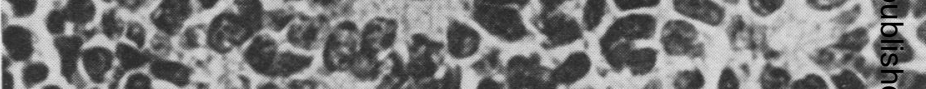

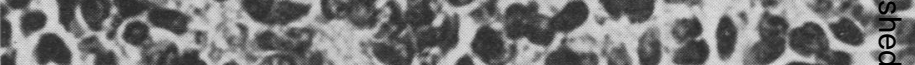

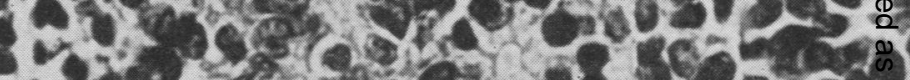

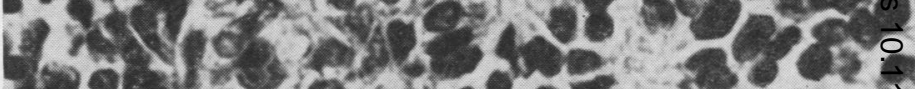

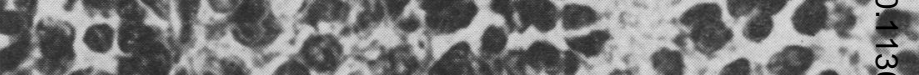

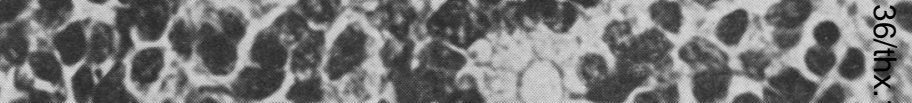

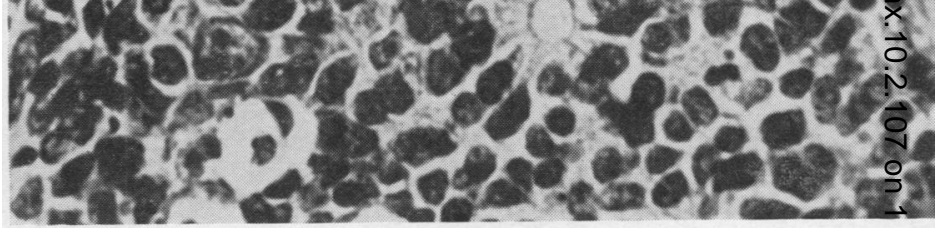

Fig. 5

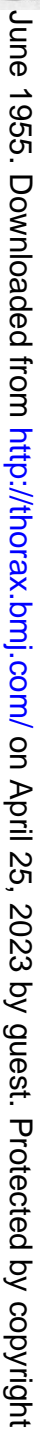




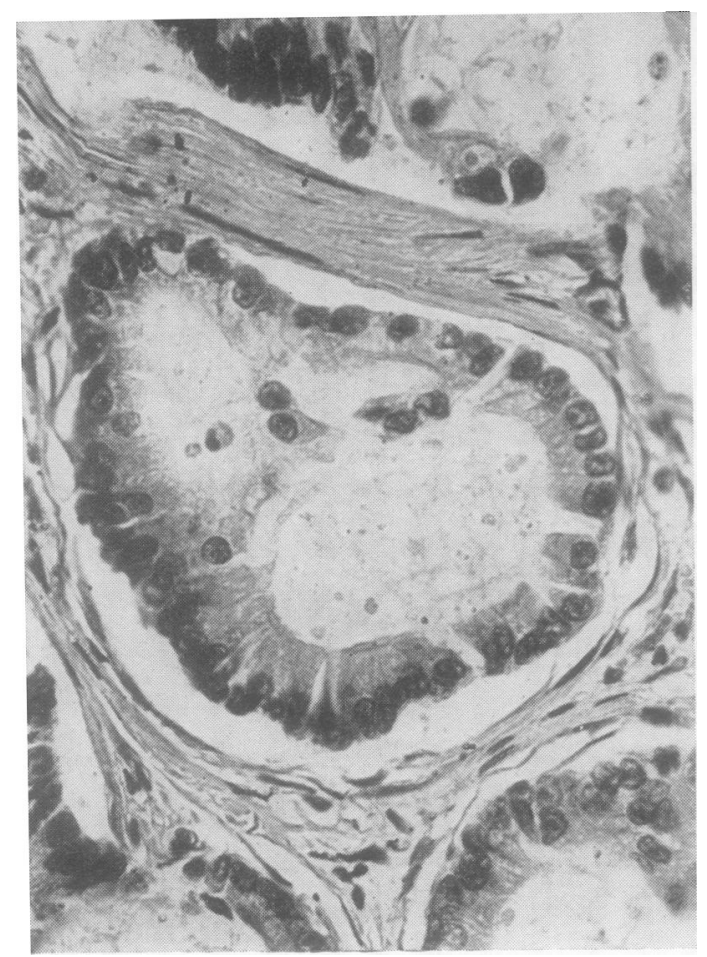

FIG. 7

FIG. 7.-Haematoxylin and eosin. Welldifferentiated adenocarcinoma showing tubule formation and mucus production, $\times 320$.

Fig. 8.-Haematoxylin and eosin. Socalled "alveolar cell" carcinoma showing regular columnar cells lining thickened alveolar septa, $\times 270$.

FIG. 9.-Haematoxylin and eosin. Poorly differentiated adenocarcinoma. Other parts of this tumour showed occasional tubule formation, $\times 1,200$.

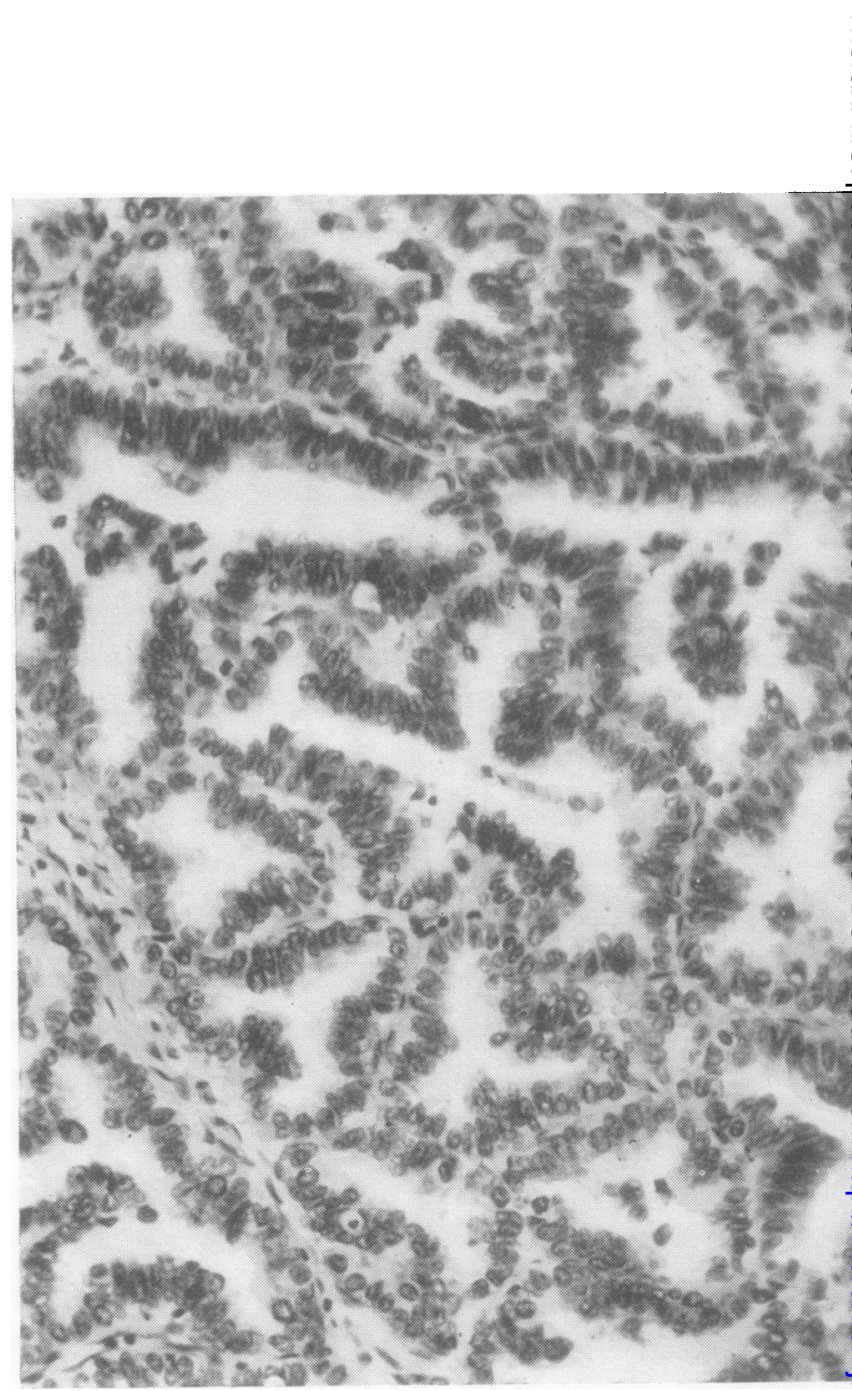

FIG. 8

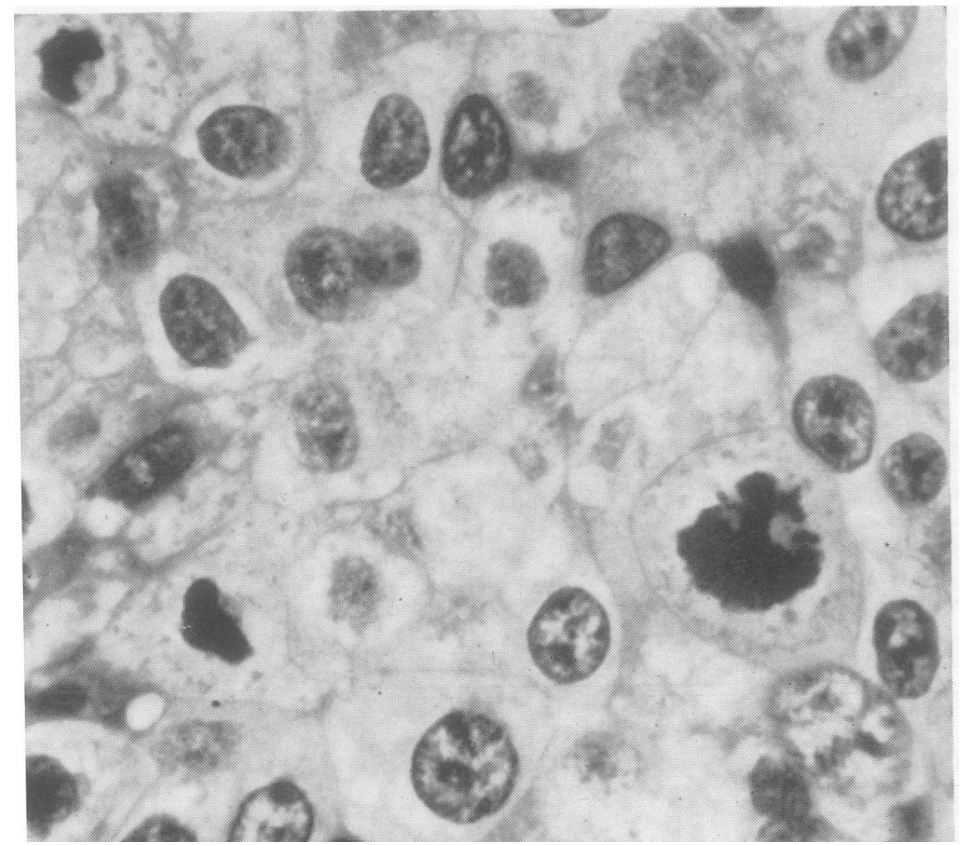

FIG. 9 
differentiation into cells of recognizable squamous type (Fig. 6); (ii) there was no indication of tubule formation or any areas of oat-cell growth.

In some cases the bronchial epithelium adjacent to the tumour showed an appearance similar to that seen in Bowen's disease of the skin. It is probable that some squamous-celled lung tumours start as intra-epidermal carcinomata. Papanicolaou and Koprowska (1951) describe a case in which multiple lesions were found. In the present series basal palisading of the cells was common, and in some cases the appearances resembled those seen in tumours of the urinary tract and might well be termed transitional-cell carcinomata. In all cases, however, frankly squamous growth was present in other parts of the tumour and it was not practicable to make this a separate group.

(3) AdENOCARCINOMA.-These tumours showed evidence of glandular function or structure. The well-differentiated tubular growths presented no difficulty (Fig. 7), and in all except one of the post-mortem cases mucus production could be demonstrated. The so-called alveolar cell carcinoma (Fig. 8) was regarded as a type of welldifferentiated adenocarcinoma having a multifocal origin from bronchioles and showing extensive implantation metastases. In less differentiated tumours, tubule formation was less marked and in a few cases absent. The cells, however, presented a characteristic appearance; they were polygonal in shape and showed large, spherical, or slightly oval vesicular nuclei and abundant ground-glass or vacuolated cytoplasm containing mucus (Fig. 9). Mucus was found in all of these cases.

(4) Polygonal-cell Carcinoma.-A fourth group was required for growths composed of polygonal cells showing neither glandular nor squamous differentiation (Fig. 10). They did not resemble oat-cell tumours and were probably anaplastic members of the squamous or adenocarcinomatous groups.

(5) Invasive AND Metastasizing Adenoma.Obvious adenomata were excluded from the series, but one case was encountered in which the nakedeye appearances were typical of carcinoma while the histology was that of adenoma. Metastases were present in the regional bronchopulmonary lymph nodes.

SECONDARY ChANGes.-The secondary changes which may occur in any type of tumour are three:

Squamous Metaplasia.-Since squamous metaplasia is not uncommon in the epithelium lining the bronchi and bronchioles, it is not surprising that it is frequently found in tumours of the lung.
It is most common in the adenocarcinomata (Fig. 11), but although this was not mentioned by some authors (Patton and others, 1951a), Phillips, Basinger and Adams (1950), using a whole section technique, found squamous metaplasia to be present in all their nine adenocarcinomata. In our series it was found in about $19 \%$ of the surgical and $12 \%$ of the necropsy adenocarcinomata. Two of the latter were of special interest: in both the primary tumour appeared to be squamous while the secondaries were mainly adenocarcinomatous. It is evident that squamous metaplasia may be so extensive that the parent type of growth is largely obscured by this secondary change.

Squamous metaplasia was also found in polygonal and oat-cell growths. In the latter it was uncommon to find frank keratinization, this being present in only $6 \%$ of our cases. A squamoid appearance with occasional prickle-cell formation was, however, less uncommon and has been noticed by others (Bryson, personal communication).

Clear Cell Formation.-It was not uncommon to find clear cells laden with glycogen in an otherwise typical adenocarcinoma (Fig. 12). In a few cases this cell type predominated and the appearances bore a striking resemblance to those seen in Grawitz tumours. The cells contained no fat and there was no evidence that they were secondary to renal neoplasms. Clear-cell areas were also found in squamous growths, whilst some clear-celled tumours were undifferentiated and therefore included in the polygonal group.

Giant Cell Formation.-Giant cells were found in some examples of all types of growth, being least conspicuous in the oat-cell tumours. In some squamous-celled tumours pleomorphic growth with spindle and giant cells was confined to intrabronchial snouts and it appeared that this was the result of growth under adverse conditions. In other cases giant cell formation was not restricted to any one part of the growth.

\section{RESULTS}

The results of the histological classification of the surgical and post-mortem series are shown in Table III.

Squamous metaplasia was found in six $(19 \%)$ of the surgical adenocarcinomata and in $10(22 \%)$ of the necropsy group. There are some observations with regard to the oat-cell carcinomata which are of interest; nearly half $(48.5 \%)$ of the surgical group showed evidence of tubular differentiation, while this was present in only $18.6 \%$ of the necropsy series. With post-mortem material the growth was 


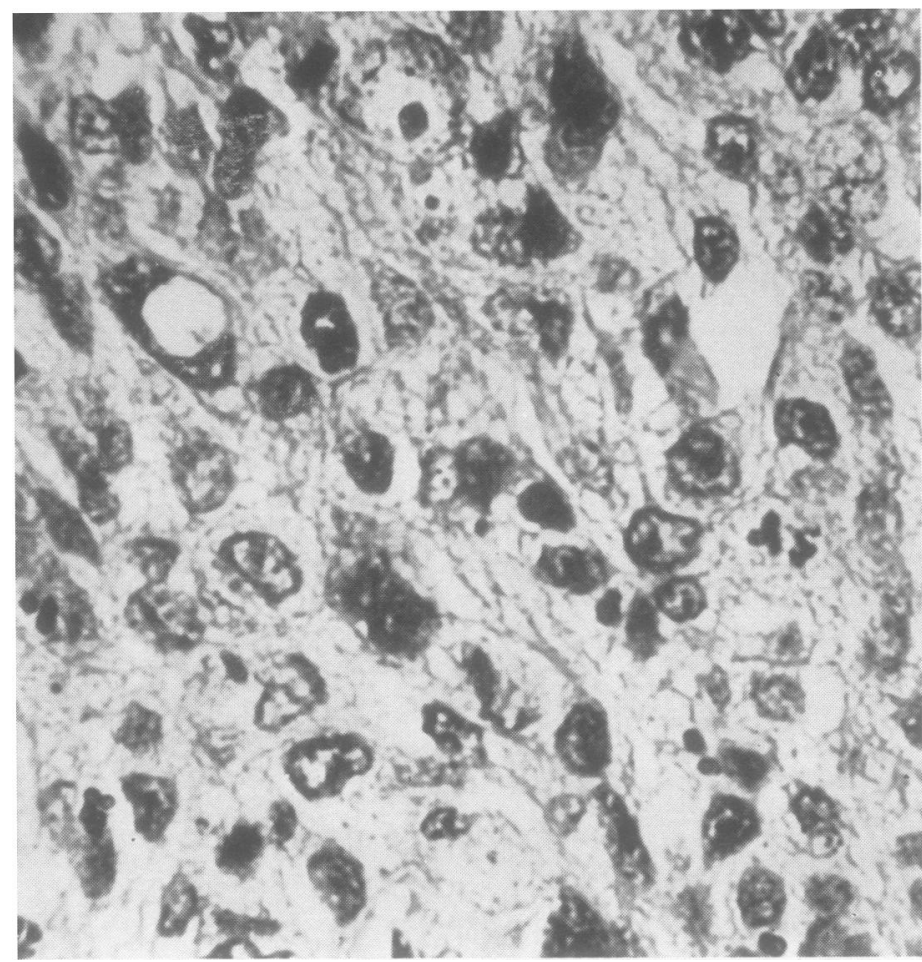

FIG. 10.-Haematoxylin and eosin Polygonal cell carcinoma, > 960 .

Fig. 11.-Haematoxylin and eosin Adenocarcinoma with tubule formation showing an area of squamous metaplasia with keratinization, 170.

FIG. 12.-Haematoxylin and eosin Poorly differentiated adenocarcinoma showing clear cell formation: these cells contain glycogen, 270
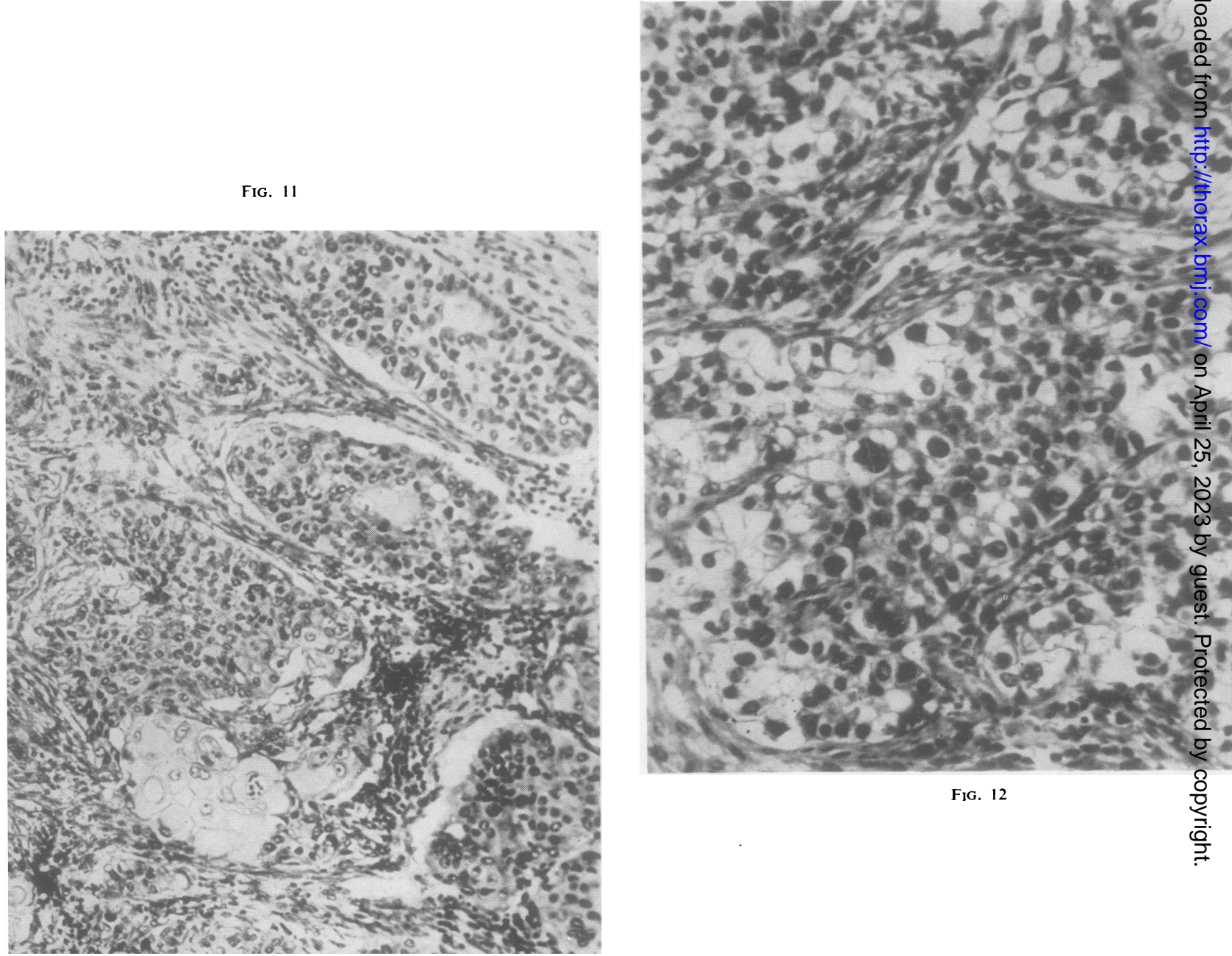
TABLE III

HISTOLOGICAL CLASSIFICATION OF 207 SURGICAL AND 159 NECROPSY SPECIMENS OF LUNG CANCER

\begin{tabular}{|c|c|c|c|c|}
\hline & \multicolumn{2}{|c|}{ Surgical Series } & \multicolumn{2}{|c|}{ Necropsy Series } \\
\hline & $\begin{array}{l}\text { No. of } \\
\text { Cases }\end{array}$ & $\%$ & $\begin{array}{l}\text { No. of } \\
\text { Cases }\end{array}$ & $\%$ \\
\hline $\begin{array}{l}\text { Squamous-cell carcinoma } \ldots \\
\text { Adenocarcinoma } \ldots \\
\text { Oat-cell carcinoma .. } \\
\text { Polygonal-cell carcinoma }, . . \\
\text { Metastasizing “" adenoma ".. } \\
\text { Unrecognizable owing to poor } \\
\text { histology .. } \ldots\end{array}$ & $\begin{array}{r}125 \\
32 \\
33 \\
16 \\
1 \\
0\end{array}$ & $\begin{array}{c}60.4 \\
15.5 \\
15.9 \\
7.7 \\
0.5 \\
0\end{array}$ & $\begin{array}{r}32 \\
45 \\
59 \\
17 \\
0 \\
6\end{array}$ & $\begin{array}{c}20 \cdot 1 \\
28 \cdot 3 \\
37 \cdot 1 \\
10 \cdot 7 \\
0 \\
3 \cdot 8\end{array}$ \\
\hline
\end{tabular}

often necrotic and the cell details obscured; recog. nition of differentiation was more difficult under such circumstances, but nevertheless we think that the difference is significant. Table IV shows the

TABLE IV

33 RESECTED OAT-CELL TUMOURS CLASSIFIED ACCORDING TO TUMOUR SIZE AND DIFFERENTIATION

\begin{tabular}{lll|c|c}
\hline \multicolumn{2}{c|}{$\begin{array}{c}\text { Size } \\
\text { of Tumour }\end{array}$} & $\begin{array}{c}\text { No. of } \\
\text { Cases }\end{array}$ & $\begin{array}{c}\text { \% Showing } \\
\text { Differentiation }\end{array}$ \\
\hline Giant &. &. & 3 & 100 \\
Large & $\cdots$ & $\cdots$ & 10 & 60 \\
Medium & $\cdots$ & $\cdots$ & 16 & 37 \\
Small & $\cdots$ & $\cdots$ & 4 & 25 \\
\hline
\end{tabular}

correlation between differentiation and tumour size, and although the numbers are small the results suggest that the diferentiated oat-cell tumours are more liable to remain localized and therefore removable.

\section{Discussion}

There seems little doubt that the confused histological nomenclature of lung carcinoma is due to difficulties in interpretation of histological appearances rather than any intrinsic complexities in the growths themselves. A purely descriptive classification like that used by Willis is more useful than one in which the limits of each group are not defined; Willis and Barnard have both emphasized the fact that if sufficient care is taken several cell types may be found in many lung cancers. In those classifications which do not recognize such " mixed" growths, it must be assumed that either the predominant cell type is accorded preference or that insufficient material was examined. With such systems the classification of a tumour is dependent upon individual bias or upon the thoroughness with which the tumour is searched.

In our study of lung cancer we have encountered " mixed" tumours, but we think that the appearances are due either to secondary changes such as squamous metaplasia or to differentiation in the oat-cell tumours.
We are convinced that the main difficulty in classifying carcinoma of the lung is connected with the oat-cell growths. Most authors, including Barnard, have simply called them anaplastic; we maintain that this is a mistake and that the oat-cell tumour is a definite entity. It has a characteristic appearance and should therefore be kept separate from the undifferentiated members of the other types of carcinoma. The oat-cell growths, as shown by Barnard, are sometimes differentiated and show the formation of tubules; these structures are lined by oat-cells, and the tumours in which they are found should still be classified as oat-cell growths. They do not secrete mucus and may be of central type (Walter and Pryce, p. 117). The ordinary adenocarcinoma, whether differentiated or undifferentiated, is quite unlike these oat-cell tumours; secretion of mucus is generally evident and the origin al nost invariably peripheral. The differentiated members of this group are often columnar-celled, while the undifferentiated members are polygonal-celled, usually with large vesicular nuclei and cytoplasm which is $\mathrm{g}$ anu'ar or foamy.

There has never been any difficulty in classifying squamous tumours in which there is no evidence of glandular or oat-celled structure. However, some adenocarcinomata and oat-cell tumours show squamous areas and we consider that this is merely metaplasia and should not be allowed to confuse the issue. Other appearances, such as the formation of clear cells or giant cells, should also be regarded as secondary change, which, like squamous metaplasia, may be so widespread as to make true identification difficult.

\section{SUMMARY}

The conflicting features of some published histological classifications of lung cancer are briefly reviewed. The view that the tumours are so pleomorphic that classification serves no purpose has not been confirmed. A consecutive series of 207 resected lung cancers has been divided into five distinct types:

\begin{tabular}{|c|c|c|c|}
\hline Oat-cell carcinoma & & & $15.9 \%$ \\
\hline Squamous-cell carcinoma & & & .4 \\
\hline Adenocarcinoma $\quad$. & . & & 1 \\
\hline Polygonal-cell carcinoma & - & & $\cdot 7$ \\
\hline Malignant " adenoma" & . & .. & \\
\hline
\end{tabular}

The oat-cell tumours are described as forming a distinct group, and in nearly half the cases there was definite differentiation with the formation of tubules and rosettes; these differentiated oat-cell tumours have not been generally recognized in the past, and it is suggested that they have frequently been confused with the ordinary adenocarcinoma 
even though the cells are of typical oat type. In no case was mucus production found, although this was usual in the ordinary adenocarcinoma. There is some evidence that these differentiated oat-cell tumours are more amenable to surgical removal than are the undifferentiated members.

Squamous metaplasia, clear cell formation, and giant cell formation are regarded as secondary changes liable to occur in any histological type of growth. Any tumour showing glandular function or structure (excluding differentiated oat-cell growths) is classified as an adenocarcinoma regardless of any secondary changes: the value of specific staining for mucus is described. Similarly any tumour showing oat-celled areas is placed in the oat-cell group, while, if squamous growth only is present, the tumour is classified as squamous-cell carcinoma. Tumours showing neither squamous nor glandular differentiation and which were not oat-celled are described as polygonal cell carcinomata. No truly " mixed" growths have been encountered, and it is concluded that the main difficulties in classifying cancer of the lung are due either to secondary changes such as squamous metaplasia or to differentiation in the oat-cell growths.

A series of 159 necropsy specimens was examined histologically and the following incidence found:

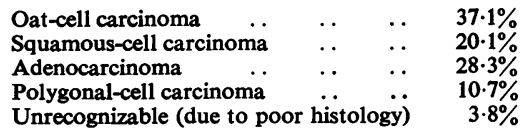

We wish to acknowledge the help and advice of Mr. T. Holmes Sellors under whose direction one of us (J. B. W.) has been working, and we are grateful to the British Empire Cancer Campaign for a grant to study lung cancer. Our thanks are due to Professor W. D.
Newcomb for his continued interest in this work, and $\underset{\vec{\rho}}{\overrightarrow{3}}$ we are greatly indebted to Dr. E. Nassau and Dr. K. R. Stokes for providing facilities at Harefield Hospital; also to Dr. K. F. W. Hinson for material from the London Chest Hospital. We are grateful to Dr. P. E. Baldry for his help during the early part of this work and to Mr. M. Turney for photographic assistance. Finally we wish to record our sincere appreciation to the many surgeons who have made their notes and records available.

\section{REFERENCES}

Aufses, A. H. (1953). J. Mt Sinai Hosp., 20, 212.

Barnard, W. G. (1926), J. Path. Bact., 29, 241.

Barnar(1938). Unio Internationalis Contra Cancrum Acta, 3, 213

Björk, V. O. (1947). Acta chir. scand., 95, Suppl. 123. 3, 213. Bogardus, G. M., Adams, W. E., and Phillips, F. J. (1950). J. thorac. Brooks, W. W. D. W., Davidson, M., Thomas, C. Price, Robson, K., and Smithers, D. W. (1951). Thorax, 6, 1

Brown, D. E. M. (1952). Brit. J. Radiol., n.s., 25, 472.

Bryson, C. C., and Spencer, H. (1951). Quart. J. Med., 20, 173. Buchberg, A., Lubliner, R., and Rubin, E. H. (1951). Dis. Chest, 20, 257.

Carlisle, J. C., McDonald, J. R., and Harrington, S. W. (1951). त J. thorac. Surg., 22, 74

Christiansen, T. (1953). Brit. J. Cancer, 7, 428.

Ewing, J. (1940). Neoplastic Diseases, 4th ed., ch. 41. Saunders, of Philadelphia and London.

Fried, B. M. (1938). Unio Internationalis Contra Cancrum Acta, 3 153.

Galluzzi, S., and Payne, P. M. (1955). Pe:sonal communication.

Gebauer, P. W. (1941). J. thorac. Surg., 10, 373.

Graham, E. A. (1941). Discussion, J. thorac. Surg., 10, 397.

Jakobsen, A. (1953). Brit. J. Cancer, 7, 423.

Koletsky, S. (1938). Arch. intern. Med., 62, 636.

Kreyberg, L (1952). Brit. J. Cancer, 6, 112.

McBurney, R. P., McDonald, J. R., and Clagett, O. T. (1951). J. @ thorac. Surg., 22, 63.

McDonald, J. R., McBurney, R. P., Carlisle, J. C., and Patton, M. M. (1951). Ibid., 22, 62

Ochsner, A., DeBakey, M., Dunlap, C. E., and Richman, I. (1948). Ibid., 17, 573.

O’Keefe, J. J. (1948). Arch. intern. Med., 82, 345.

Ormerod, F. C. (1937). J. Laryng., 52, 733.

Papanicolaou, G. N., and Koprowska, I. (1951). Cancer, N.Y., 4,

Patton, M. M., McDonald, J. R., and Moersch, H. J. (1951a). J. thorac. Surg., 22, 83

- (1951b). Ibid., 22, 88.

Phillips, F. J., Basinger, C. E., and Adams, W. E. (1950). Ibid. $19,680$.

Rienhoff, W. F. (1947). Ann. Surg., 125, 541.

Shorvon, L. M. (1947). Brit. J. Radiol., n.s., 20, 443.

Willis, R. A. (1948). Pathology of Tumours, ist ed., ch. 19. Butterworth, London. 